\title{
Спектральные и фотоэлектрические характеристики гидрохимически осажденных пленок твердых растворов замещения $\mathrm{Cd}_{x} \mathrm{~Pb}_{1-x} \mathrm{~S}$
}

\author{
В.Ф. Марков ${ }^{1,2)}$, Л.Н. Маскаева ${ }^{1,2)}$, А.Д. Кутявина ${ }^{1)}$, И.В. Ваганова ${ }^{2)}$, И.Н. Мирошникова ${ }^{3)}$, \\ Б.Н. Мирошников ${ }^{3)}$ \\ ${ }^{l}$ Уральский федеральный университет имени первого Президента России Б.Н. Ельцина, \\ Екатеринбург, 620002, Мира 19 \\ ${ }^{2}$ Уральский институт ГПС МЧС России, Екатеринбург, 620022, Мира 22 \\ ${ }^{3}$ Московский энергетический институт, Москва, 111250, Красноказарменная 14 \\ тел:+7 (343) 375-9318, эл. почта: v.f.markov@urfu.ru
}

DOI 10.34077/RCSP2019-51

Химически осажденные пленки твердых растворов (ТР3) различного состава $\mathrm{Cd}_{x} \mathrm{~Pb}_{1-x} \mathrm{~S}$ являются фоточувствительными в видимой и ближней ИК-области спектра. После извлечения из реакционной смеси они не требуют сенсибилизации и готовы к практическому использованию.

Диапазон спектральной чувствительности ТPЗ $\mathrm{Cd}_{x} \mathrm{~Pb}_{1-x} \mathrm{~S}$ зависит от содержания в них кадмия. На спектральных характеристиках пленок $\mathrm{Cd}_{x} \mathrm{~Pb}_{1-x} \mathrm{~S}$ при повышении содержания сульфида кадмия в ТРЗ от 0 до 17 мол.\% “красная” граница фоточувствительности сдвигается в коротковолновую область с 3.1. до 1.6 мкм, а максимум фоточувствительности с 2.5 до 1.2 мкм.

Состав ТРЗ можно менять не только за счет изменения концентрации соли кадмия в реакторе, но и путем использования солей кадмия с различной анионной компонентой, а также, учитывая неоднородность состава по толщине пленки, регулированием времени осаждения слоя. При замене 0.06 моль/л $\mathrm{CdSO}_{4}$ в реакторе таким же количеством $\mathrm{CdI}_{2}$ при прочих равных условиях содержание $\mathrm{CdS}$ в TP3 уменьшается с 11.1 до 5 мол.\%. Поэтому максимум спектральной чувствительности сдвигается с 1.90 мкм до 1.45 мкм. Для пленок толщиной .3-1.0 мкм спектральная характеристика имеет выраженный максимум на длине волны 0.5 мкм, соответствующий фоточувствительности индивидуального $\mathrm{CdS}$, с которой при этих условиях начинается формирование пленки ТРЗ. C увеличением толщины пленки происходит постепенный сдвиг спектральной кривой в длинноволновый диапазон вследствие уменьшения в составе ТРЗ мольной доли кадмия.

Возможность формирования пленок $\mathrm{Cd}_{x} \mathrm{~Pb}_{1-x} \mathrm{~S}$ различного состава обеспечивает получение материалов с регулируемым положением максимума и “красной” границы спектральной характеристики во всем ближнем ИК-диапазоне. Особый интерес представляет ТРЗ $\mathrm{Cd}_{0.06} \mathrm{~Pb}_{0.94} \mathrm{~S}$, имеющий эту характеристику практически аналогичную с германием, однако, обладающий более высоким темновым сопротивлением, обеспечивая согласование в микроэлектронных схемах.

Пленка $\mathrm{PbS}$ без сенсибилизирующих добавок и проведения отжига, практически не обладает фоточувствительными свойствами. Введение в реактор соли кадмия сенсибилизирует пленку $\mathrm{PbS}$. При переходе от индивидуального $\mathrm{PbS}$ к $\mathrm{TP} 3 \mathrm{Cd}_{x} \mathrm{~Pb}_{1-x} \mathrm{~S}$ тип проводимости изменяется от “ $n$ ” к " $p$ ”, а концентрация носителей снижается на 3-5 порядков. С увеличением содержания кадмия в ТРЗ уровень вольт-ваттной чувствительности пленок возрастает, достигая наибольших значений вблизи области максимума на рис. Причиной этого могут являться хаотически распределенные инверсионные "пятна" $\mathrm{CdS}$ на гранях кристаллитов $\mathrm{Cd}_{x} \mathrm{~Pb}_{1-x} \mathrm{~S}, \quad$ имеющие адсорбционную природу.

Вольт-ваттная чувствительность пленок находится в пределах $(0.5-1.0) \cdot 10^{3}$ В/Вт при использовании соли $\mathrm{CdI}_{2}$, возрастая до (1.0-

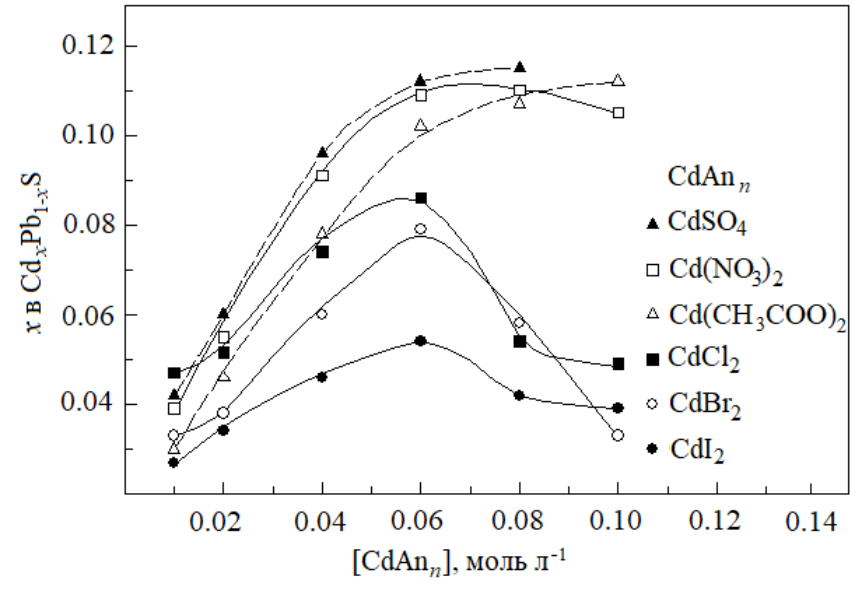

Рис. Содержание кадмия, $x$, в ТР3 $\mathrm{Cd}_{x} \mathrm{~Pb}_{1-x} \mathrm{~S}$ от концентрации солей кадмия $\mathrm{CdSO}_{4}, \mathrm{Cd}\left(\mathrm{NO}_{3}\right)_{2}$, $\left.\mathrm{Cd}\left(\mathrm{CH}_{3} \mathrm{COO}\right)_{2}, \mathrm{CdCl}_{2}, \mathrm{CdBr}_{2}, \mathrm{CdI}_{2}\right)$ в водной реакционной смеси

$2.0) \cdot 10^{4} \mathrm{~B} / \mathrm{B}$ для тех же концентраций $\mathrm{Cd}\left(\mathrm{CH}_{3} \mathrm{COO}\right)_{2}$. при относительно малых значениях времени фотоотклика (30-120 мкс). По вольт-ваттной чувствительности и постоянной времени пленки ТРЗ $\mathrm{Cd}_{x} \mathrm{~Pb}_{1-x} \mathrm{~S}$ в ближней ИК-области спектра не имеют аналогов, и могут найти применение в оптоэлектронных устройствах. 